\title{
The politics of Pride: representing relegated sexual identities in Northern Ireland
}

\author{
Dr Marian Duggan
}

Sheffield Hallam University

\section{Introduction}

$\mathrm{N}$ orthern Ireland can be seen as a politically sensitive society where religion and politics often intersect to govern from a morally conservative standpoint. The vocal opposition to homosexuality demonstrated by Northern Irish politicians and annual picketers of the Gay Pride parade in Belfast demonstrates how the feminist mantra of "the personal is political" resonates for sexual minorities in Northern Ireland. As a result, Pride has become a political platform from which to illustrate the ongoing prejudice faced by lesbian, gay, bisexual and transgender $\left(\mathrm{LGBT}^{1}{ }^{1}\right.$ communities. In particular, several organisers of Pride have drawn attention to the harmful and inflammatory comments made by morally conservative Northern Irish Members of the Legislative Assembly (MLAs) and the fact that legislation enacted to protect LGBT people from persecution remains unused. Many hate-crime theorists claim that, in order to address the "everyday" or low-level forms of identity-based prejudice, such as homophobia, a clear indication needs to be given that such hostility is not tolerated. ${ }^{2}$ If this is not the case, then prosecuting only the extreme levels of homophobic violence appears to condone other forms of victimisation, placing prejudice on a continuum of severity. This appears to be the case in Northern Ireland, where only the most serious cases of violence motivated by homophobic hatred have warranted recognition at the prosecution stage. ${ }^{3}$

However, taking the position that such forms of hatred are often situated, and tolerated, within a wider prejudicial culture, this article examines why similar displays of antihomosexual sentiment which incur punishment in Great Britain evade disciplinary or criminal action against politicians in Northern Ireland. Citing examples of some of the disparaging claims made about homosexuality in Northern Ireland, the paper explores whether the religious exemptions designed to protect freedom of speech may be impacting on the efficacy of equality legislation truly to address homophobic hostility. In doing so, the

1 Although transgender identities are based upon gender differences as opposed to sexual identities, due to the minimal numbers of trans-identifying people in Northern Ireland, they are often conflated with lesbian, gay and bisexual groups.

2 See B Perry, In the Name of Hate: Understanding hate crime (New York: Routledge 2001); B Perry, "Accounting for hate crime: doing difference" in B Perry (ed.), Hate and Bias Crime: A reader (New York: Routledge 2003); P Iganski, Hate Crime and the City (Bristol: The Policy Press 2008).

3 Several of these cases are detailed later in the paper. 
article assesses the wider remit of Northern Ireland's politically tenuous past and continuing sensitive present, challenging the true value of sexual orientation equality legislation in a culture where moral conservatism reigns supreme.

Northern Ireland's socio-political history proves important in contextualising freedoms and equalities in light of its troubled past. Issues surrounding identity and representations of difference in Northern Ireland have a long and somewhat contentious history, intensifying during a period of political instability known as the "Troubles". The Troubles dominated politics and society in Northern Ireland from the late 1960s to the late 1990s but, it is argued in this paper, can be seen as continuing subtly to inform contemporary political and social life. The signing of the Belfast (Good Friday) Agreement in 1998 signalled an end to the worst period of the conflict and the start of the ongoing and relatively successful peace process. The 1998 Agreement sought to address many of the inequality issues informing hostile relations between Protestant and Catholic community members in Northern Ireland, accounting not only for sectarian divisions but also differences inferred upon the basis of race, religion, sexual orientation and disability. Certainly, it can be argued, in the case of sexual orientation equality and anti-discrimination measures, Northern Ireland's commitment to equality has proved beneficial to obtaining legal protections that otherwise may have proved difficult to implement organically. ${ }^{4}$ Similarly, s. 75 of the Northern Ireland Act 1998, requires statutory bodies to have due regard for the need to promote equality of opportunity and good relations. LGBT communities were included as a minority group requiring legal recognition within this section.

Subsequent legislation relating to sexual orientation included freedom from workplace discrimination in the Employment Equality (Sexual Orientation) Regulations (Northern Ireland) 2003; freedom to register partnerships in the Civil Partnership Act 2004; freedom from victimisation or discrimination in the Criminal Justice (No 2) (Northern Ireland) Act 2004; and recognition as warranting equal treatment under the Equality Act (Sexual Orientation) Regulations (Northern Ireland) 2006. However, more morally conservative members of Christian organisations have used faith-based arguments to avoid wholly complying with several laws designed to protect sexual minorities from discrimination. ${ }^{5}$ For example, Christian adoption organisations in Northern Ireland were in extended negotiations with the British government about complying with the Equality Act (Sexual Orientation) Regulations (Northern Ireland) 2006 - whereby they would be required to accept lesbians and gay men as potential adopters - despite being given a lengthy amount of time to "adjust" to the new law. This need to account for religious wishes is indicative of the binary distinction drawn between sexuality and spirituality in Northern Ireland by political elites and members of the clergy which construct homosexuality as sinful deviance and therefore, for some, a viable target of prejudice and discrimination.

\section{Developing LGBT visibility}

The recent spate of equality legislation to protect members of LGBT communities in Northern Ireland was enacted by Westminster to the devolved Northern Ireland Assembly. The Assembly has never freely designed laws which could be seen as aiding LGBT communities. The struggle for homosexual decriminalisation exemplifies this. Following the partial decriminalisation of homosexuality in England and Wales through the Sexual Offences Act 1967, a campaign was established by several Northern Irish Democratic Unionist Party (DUP) politicians and religious leaders to stop this legislation being extended

4 The case of Dudgeon $\mathrm{v} U K$, detailed below, exemplifies this.

5 C Mitchell and J Tilley, "The moral minority: evangelical Protestants in Northern Ireland and their political behaviour”" (2004) 52(3) Political Studies 585-602. 
to Northern Ireland. This campaign, spearheaded by the Revered Ian Paisley, who at the time was head of both the DUP and the newly formed Free Presbyterian Church, garnered the support of Catholic Churches where possible, regardless of the ongoing sectarian division. ${ }^{6}$ Heavily invoking doctrinal ideologies of doom and destruction, primarily the destruction of Northern Ireland's "moral fabric", Dr Paisley's Campaign resulted in more than 70,000 Northern Irish residents (at that point $5 \%$ of the population) signing a petition opposing decriminalisation. Large advertisements in newspapers stated that enacting the law "can only bring God's curse down upon our people". 7 Additional support was garnered through the distribution of pamphlets which focused heavily upon the fear that such a law would adversely impact on social values:

We oppose the legalising of Homosexuality as we believe the practice is contrary to the Word of God and the moral standards of the people of Northern Ireland. HOMOSEXUALITY DEMANDS NOT ACCEPTANCE BUT A CURE. The legalising of homosexuality would open the floodgates of immorality, with countless other vices demanding acceptance. The consequences of such a deluge would be grim ...8

Invoking the key tenets of Northern Irish identity - faith and family - as well as the fear of chaos, DUP councillor Alan Kane ensured that his pamphlet left no doubt as to the potential destruction legalised homosexuality would bring:

Homosexuality should not be regarded as a disease but as a sin which debases individuals, degrades society and which is outrightly condemned in the Bible in the strongest possible terms . . . The demands for the legislation of homosexuality represent a serious threat to the social order and another attempt to undermine the basic tenets of morality which are held by the vast majority of decent people in Northern Ireland ... The law must act as a deterrent otherwise a society totally devoid of any form of legal control would be created, where mass murder, rapes and incestuous relationships would take place. ${ }^{9}$

The success of this campaign meant that homosexuality remained criminalised under the Offences against the Person Act 1861 and the Criminal Law (Amendment) Act 1885, which added the "gross indecency" charge, effectively criminalising all sexual contact between men. Police raids on the homes of several known members of gay rights organisations - who had formed to campaign in favour of extending the 1967 Act to Northern Ireland - led to the arrest of Jeffrey Dudgeon. This proved pivotal in the campaign for decriminalisation. In 1980, Dudgeon took a discrimination case to the European Commission of Human Rights to be screened for admissibility and to see if his claims under various Articles had any merit. In 1978, the commission found his claim under Article 8 admissible, deciding by nine votes to one that the legal prohibition of homosexual acts between men over 21 years of age breached his right to respect for his private life. The commission referred the case to the European Court of Human Rights for clarification of the law, which in turn decided to take the decision in plenary as it does with important legal matters so it could have an authoritative decision. On 22 October 1981, the court in plenary

6 Northern Ireland Gay Rights Association (NIGRA), Information Sheets and Memoranda Issued by Various Gay Rights Groups, Mainly NIGRA May 1974-October 1980 Ref No D/3762/1/4/2 (Belfast: Public Records Office Northern Ireland 1979).

7 D McKittrick, "Paisley's power switched off", Irish Times, 20 October 1977, available at www.irishtimes.com/newspaper/archive/1977/.

8 NIGRA, "Article from THES 14 May 1979", Gays in Ulster: A report of recent developments Ref No D/3762/1/1/5 (Belfast: Public Records Office Northern Ireland 1979).

9 NIGRA, Information Sheets and Memoranda Issued by Various Gay Rights Groups, Mainly NIGRA May 1974-October 1980 Ref No D/3762/1/4/2 (Belfast: Public Records Office Northern Ireland 1979). 
(19 judges) agreed with the commission's position by 15 votes to 4, ordering that decriminalisation be applied to homosexual acts in private in Northern Ireland, which it duly was in $1982 .{ }^{10}$

During this time, LGBT visibility in Northern Ireland was somewhat limited to particular venues in Belfast city centre which would otherwise have been empty due to the ongoing conflict. During the worst years of the Troubles, the development of "gay space" was aided by the curfews imposed within Belfast and people's fears of being in the city centre at night. Several proprietors of bars, clubs and hotels were driven by an economic need to capitalise on the LGBT population which ventured into the largely vacant city centre in the evenings. This allowed a flourishing LGBT community to develop, alongside the emerging punk subculture and several members of the deaf community, who also used these social spaces. This state of affairs continued until the Chariot Rooms, a gay-owned public house, became established as one of the first permanent gay spaces in Northern Ireland. Gradually, as paramilitary groups called ceasefires and the violence began to subside, this increasingly diverse LGBT community became more visible in Belfast. At the same time, an increasingly visible LGBT scene was also appearing in the Foyle area. However, for the most part, LGBT visibility in Northern Ireland remained limited to these two locations, or occasional nights in predominantly "heterosexual" bars in other towns. As a result, the emergence of the first Gay Pride parade was a monumental occurrence, putting Northern Ireland's growing LGBT community on the social and political map.

\section{Parading and Gay Pride}

The first ever Gay Pride parade was held in 1970 in America, following the three-day riot between police and LGBT patrons at the Stonewall Bar in New York in July 1969. This riot ensued as a result of perceived police harassment in routinely raiding the venue and exposing and vilifying many of the patrons in press reports afterwards. The resulting civil rights demonstrations and campaigns led to the recognition of social changes and perceptions towards homosexuality in developed Western societies. This was aided by homosexuality being removed from the list of psychiatric disorders outlined by the American Psychiatric Association and later the World Health Organisation. The implementation of legislation decriminalising homosexuality was testament to emerging research looking at the social construction of identity and the subsequent impact of this on prejudice and discrimination towards minority groups. In commemoration of this important turning point, Gay Pride parades in many Western societies have flourished, although in some religiously conservative cultures the issue of Gay Pride parades continues to be a contested site of struggle. ${ }^{11}$ For communities where Gay Pride parades are more welcomed, they are important means of community interaction, often involving a series of events in which people of all sexual orientations are invited to join.

As part of the growing drive for visibility and acceptance in Northern Ireland, in 1990, several LGBT activists undertook to organise the first Gay Pride march in Belfast. Although small in comparison to contemporary parades, it has grown in size to become a staple feature in Northern Ireland's calendar of summer events. The geographical space used by the parade is an important part of the visibility debate. The Gay Pride parade proceeds through Belfast city centre, around the City Hall and back up to the Cathedral Quarter: this is an area which unofficially constitutes Belfast's "gay space" by virtue of its gay nightclub, handful of gay-owned and run bars, and two gay-themed saunas, all within close proximity

10 Dudgeon v UK (1982) 4 EHRR 149.

11 See, for example, P Jackson, "Gay Pride challenges Moscow", BBC News, 17 February 2006, available at http://news.bbc.co.uk/2/hi/europe/4714818.stm. 
to one another. LGBT visibility in Belfast is not constrained to this area, but there are few other spaces or bars which cater to LGBT patrons in a specific manner. Once the Gay Pride parade exits the Cathedral Quarter, it leaves the safety of unofficially demarcated "gay space", and proceeds through areas that are primarily, albeit invisibly, "heterosexual" as the majority of the people occupying these spaces "can take the street for granted as a 'commonsense' heterosexual space precisely because they take for granted their freedom to perform their own identities". 12 This is an important factor in exposing the otherwise invisible heteronormativity which is predominate in Northern Irish societies. The heterosexing of space "is naturalized to the point where heterosexuals are not aware of the heterosexing of space in the same way that sexual dissidents are". ${ }^{13}$ However, during this parade, representations of sexual dissidence dominate this otherwise naturalised heteronormative space. Corteen qualifies the "heterosexual street" as not needing overt actions or demonstrations to determine its sexuality, but where these are employed, they range from "heterosexual couples kissing and holding hands as they make their way down the street, to advertisements and window displays which present images of contented 'nuclear' families". ${ }^{14}$ Marchers on the Gay Pride parade, advocating for their own families, partnerships and relationships, subvert these heterosexualised "norms", evincing the binaries upon which they are routinely placed. However, rather than engage with this as a viable alternative, such demonstrations are used to further denigrate "false" representations of intimacy and the family. As Gail Mason outlines, even the language used to denote such representations illustrates this failure to recognise the validity of sexual difference:

We need look no further than the popular and longstanding refrain against those who "flaunt" their homosexuality to realise that the very suggestion that homosexuality can be flaunted is itself the product of the social and the political hush that has historically enveloped the subject of same-sex sexuality. ${ }^{15}$

Because Gay Pride utilises and subverts space in this way, those involved in the parade are often deemed to be "flaunting" their sexuality by those who have chosen to come and protest against the parade, despite the fact that the protestors have freely chosen to occupy this space at that particular time. As 2010 marks the 20th anniversary of Northern Ireland's annual Gay Pride parade, the increased frequency and number of those opposing the parade has indicated the ever-increasing need for a platform from which to demonstrate the danger many members of the LGBT community still face as a result of harmful and often archaic ideologies which cast them as subcultural, sexual, predatory, diseased or dangerous individuals. ${ }^{16}$

\section{CONTESTING THE PARADE}

Parades in Northern Ireland occasionally attract a level of contention as a result of the historic socio-political divides drawn along national and religious identity lines. ${ }^{17}$ Although they date back to the eighteenth century, modern-day parades in Northern Ireland are symbols of remembrance of key historical events. The parade season in Northern Ireland

12 G Valentine, “(Re)negotiating the "heterosexual street”" in N Duncan (ed.), Body Space: Destabilising geographies of gender and sexuality (London: Routledge 1996), p. 149.

13 K Corteen, "Lesbian safety talk: problematizing definitions and experiences of violence, sexuality and space" (2002) 5(3) Sexualities 259-80, at 261.

14 Valentine, “(Re)negotiating”, n. 12 above, p. 146.

15 G Mason, "Body maps: envisaging homophobia, violence and safety" (2001) 10(1) Social and Legal Studies $23-44$ at 24.

16 See L Moran, The Homosexual(ity) of Law (London: Routledge 1996).

17 D McKittrick and D McVea, Making Sense of the Troubles (Belfast: Blackstaff Press 2001). 
runs from April to September, with almost 4000 parades held annually. The vast majority of these are hosted by members of Protestant/Unionist communities; one half of Northern Ireland's traditionally perceived "two-community divide". Historical sectarian divides are replicated through the problematic restructuring of parade routes designed to offset the violent clashes witnessed in previous years. Unionist marches through primarily Catholic/Nationalist areas (the other half of the divide) have contributed to the stereotypes of fear, violence and hostility that traditionally accompanied images of parades in Northern Ireland. ${ }^{18}$ Due to such disturbances, and the apparently contentious nature of some parades, a Parades Commission was established in 1997. This is an independent, quasijudicial body which ensures the adherence to the rules and regulations governing the approval and undertaking of parades. ${ }^{19}$

Unlike many of the parades held in Northern Ireland, the Gay Pride parade is not exclusionary on the basis of identity politics. Many LGBT groups in Northern Ireland actively illustrate how the Gay Pride parade is among the few non-sectarian spaces in Northern Ireland, not marked by traditional political divisions. Nevertheless, those opposed to the annual Gay Pride parade routinely apply to this commission to ban it, albeit with little success. Their opposing arguments are largely rooted in a Christian moral discourse of homosexuality as a sinful practice. In 2005, several opponents organised to produce a Stop The Parade (STP) coalition which was active between 2005 and 2008. As part of its organising against the Gay Pride parade, STP produced a (now-defunct) website which outlined its objections and proposed bases for having the commission impose a ban:

lewd and offensive festival that promotes a sinful and immoral lifestyle . . . we want to reach out to sodomites taking part in the parade to show them that there is an alternative and that they can be delivered from the bondage of sodomy by repentance from sin and faith in Jesus Christ alone. ${ }^{20}$

This assimilation of a homosexual identity with engagement in "deviant" sexual activities goes towards the legitimate construction of such identities as not natural or desirable. Additionally, the interchangeability of "homosexual" with "sodomite" omitted the recognition of women as anything other than heterosexual. STP's decision to single out Gay Pride over 4000 less peaceful, less inclusive and less cross-community parades was defended on the basis that more people living in Northern Ireland were offended by the Gay Pride parade than any other march, although no evidence was provided to support this claim. Despite describing the Gay Pride parade as "contentious", there are a greater number of far more contentious parades occurring each year which do not incur such opposition from this group of moral objectors. However, the use of this particular word by STP meant that the Parades Commission were compelled to investigate, as it was within its role to examine and potentially ban "contentious" parades in Northern Ireland. As a result, in 2005, representatives of STP and Gay Pride parade organisers were invited to meet with the Parades Commission ahead of the parade. In the meeting, several guidelines were outlined, including assurances that verbal abuse and harassment would be avoided by both parties towards the other. ${ }^{21}$ Whilst verbal abuse was ruled out, other forms of getting the moral message across were not. Therefore, innovative forms of "reaching out" to members of the

18 N Jarman and D Bryan, Parade and Protest: A discussion of parading disputes in Northern Ireland (Coleraine: University of Ulster 1996).

19 The Parades Commission's powers and duties can be found in the Public Processions (Northern Ireland) Act 1998.

20 The site was previously available at www.stoptheparade.com/ (last accessed 8 May 2008).

21 "Gay Pride protestors claim abuse", BBC News, 6 August 2005, available at: http://news.bbc.co.uk/2/hi/ uk_news/northern_ireland/4128006.stm. 
LGBT community involved STP hiring an advertising lorry emblazoned with pictures of same-sex couples accompanied with moral messages against homosexuality. They displayed the vehicle outside several popular gay venues in Belfast to "assist in conveying God's message of repentance to Belfast's sodomite community". 22 When challenged about their need to remonstrate against Pride, Jonathan Larner from STP claimed that the group was being "pigeon-holed as hateful and homophobic" but chose to make its presence known as "the far greater hate would be shown by staying at home and doing nothing". 23 This message appears to have resonated with similarly minded opponents, with increasing numbers of people protesting against the parade in recent years. There are now two identifiable sites of protest: the traditional spot outside the City Hall and more recently outside St Anne's Cathedral. The protestors are largely silent and in most cases turn their backs on the Gay Pride marchers as they pass by. Many hold large placards emblazoned with biblical passages alluding to the wrongfulness of homosexuality (and, in some cases, other perceived sins such as adultery) and the implications of this for those who engage in homosexual practices, many of which feed into archaic ideologies surrounding homosexuality in Northern Ireland. Many of the banners and placards can be perceived as offensive in nature and likely to instil fear of hostility, yet are not dealt with in such a way. Displays such as "Homosexuality is Sin" and "The wages of Sin is Death" may also be interpreted by some LGBT people in attendance as also speaking to homophobic people, condoning their prejudice towards sexual minorities. Given the media attention garnered at the annual parade, the protestors' decision to display their sentiments in written as opposed to oral format may also be tactical. Again, these passages relate mainly to male homosexuality as a result of less being written about female homosexuality in biblical passages.

However, it was the suggestion by one Pride participant in the 2007 parade that Jesus may have been homosexual that demonstrated the double standards held about claims which could or could not be made. In a matter which ended up being debated in the House of Commons, a placard reading "Jesus is a fag" incurred heavy criticism from many Northern Irish MLAs and clergy. North Belfast DUP MLA Nigel Dodds lambasted the claim as "offensive and blasphemous". ${ }^{24}$ East Belfast council member May Campbell also seized this opportunity to call for an end to future Gay Pride parades being held in Northern Ireland. She remarked that "Christians all over the province, and indeed, the world will be disgusted by this slur. If such provocative claims were made against Mohammad, Muslims would rightly be up in arms." 25 However, it was chaplain Ian Hall who was perhaps the most vociferous, stating:

This event ... was in fact a parade of perversion. The reality is that the behaviour of the sodomites is totally unacceptable. The Scriptures condemn the homosexual lifestyle in the most strident language. The Bible not only calls homosexual practices sinful but uses terms like "reprobate mind", "vile affections" and "abominations" .. . Saturday's parade brought shame and disgrace to the good name of our nation's capital ... The vast majority of Ulster

22 "Belfast Gay Pride: another successful year", Gay Belfast, 7 August 2005, available at www.gaybelfast.net/ fiveaug.htm.

23 P Jackson, "Gay Pride weathers Belfast storm", BBC News, 6 August 2005 . available at http://news.bbc.co.uk/2/hi/uk_news/northern_ireland/4739815.stm

24 "Comments", News Letter, available at www.newsletter.co.uk/news/Probe-into-39blasphemous39-GayPride.3628719.jp.

25 www.metroeireann.com/index.php?option $=$ com_content\&task=view\&id $=542 \& I$ temid $=60$. 
people regard homosexual practices as depraved and disgusting and certainly would not give their approval to this tiny minority blighting their capital city with their monstrous march. ${ }^{26}$

Interestingly, judgments made about the placard centred upon the perceived attack on religious morality and not as a personal opinion or one person's own religious perspective, effectively sidestepping the fact that the author's use of the verb "is", rather than "was", may infer that the holder is, himself, a religious person voicing a particular belief. Nevertheless, the row served to highlight the growing propensity for community and political leaders to comment with relative impunity against homosexuality in Northern Ireland.

\section{The prevalence of political homophobia}

In 2008, comments made by Iris Robinson MP caused a huge outcry from members of LGBT groups in Northern Ireland and beyond. Mrs Robinson, the wife of First Minister Peter Robinson, was the chair of the Stormont Health Committee until 2010, and therefore oversaw mental health initiatives, including those directed at helping lesbians and gay men overcome the homophobia they may be exposed to. In a live radio interview, Mrs Robinson stated that she felt homosexuality was an "abomination" and that it "nauseated" her. ${ }^{27}$ She also suggested that homosexuals could be "cured" with psychiatric treatment and promoted the services of a "very nice" psychiatrist she knew who could help to "reorientate" homosexuals back to heterosexuality. She defended these statements by claiming that she believed it was the "duty of Government to uphold God's law". ${ }^{28}$ It later emerged that Robinson had previously declared at Westminster that she believed "there can be no viler act, apart from homosexuality and sodomy, than sexually abusing innocent children". ${ }^{29}$ She had also compared homosexuals to murderers in an effort to indicate how distasteful she found homosexuality. After an investigation lasting a year, the Police Service of Northern Ireland (PSNI) stated that no action would be taken against Robinson for these public statements as she had done nothing wrong. ${ }^{30}$ Mrs Robinson remained in post for a further 18 months, only being removed from her positions of councillor, MLA and MP in 2010 following allegations of an affair with a 19-year-old family friend to whose business she granted a licence and invested $£, 50,000$ in without declaring any of the above to Parliament. ${ }^{31}$ As news of this scandal broke, it also emerged that Mrs Robinson's comments about homosexuality had occurred at the same time as the affair with her young lover was coming to an end.

This was not the first time Northern Ireland's political elites had conflated personal prejudice with political rhetoric. In 2005, Ian Paisley Jnr was censored by the Northern Ireland Policing Board - of which he was a member - for disparaging comments about the civil partnership of an adviser to former Ulster Unionist leader David Trimble. Mr Paisley denounced homosexual relationships as immoral, offensive and obnoxious, whilst ignoring

26 I Hall, “Offensive march should be banned", Irish News, 7 August 2007, available at www.irishnews.com.

27 D Young, "Gay lifestyle is 'abomination' not a mental disorder: Iris", Belfast Telegraph, 1 July 2008, available at www.belfasttelegraph.co.uk/news/.

28 “Iris Robinson: It's government's duty to uphold God's law", Belfast Telegraph, 18 July 2008, available at www.belfasttelegraph.co.uk/news/local-national/iris-robinson-itrsquos-governmentrsquos-duty-to-upholdgodrsquos-law-13912046.html.

29 "Iris: gays more vile than child abusers", Belfast Telegraph, 21 July 2008, available at www.belfasttelegraph.co.uk/news/.

30 D Gordon, “No Assembly sanctions over MP's gay remarks", Belfast Telegraph, 4 July 2009, available at www.belfasttelegraph.co.uk/news/.

31 D Batty, “Investigation launched into Iris Robinson's $f 50,000$ loan to lover”, Guardian, 22 January 2010 , available at www.guardian.co.uk/politics/2010/jan/22/iris-robinson-investigation-launched. 
PSNI statements about the rising level of homophobic attacks in Northern Ireland at the time. ${ }^{32} \mathrm{He}$ did not stop there; when in post as a junior minister in 2007 , he made the following comments in an interview with a Dublin-based music magazine:

I am, unsurprisingly, a straight person. I am pretty repulsed by gay and lesbianism. I think it is wrong. I think that those people harm themselves and without caring about it - harm society. That doesn't mean to say that I hate them. I mean, I hate what they do. ${ }^{33}$

Although he was investigated by the Assembly ombudsman as to whether or not he had breached Assembly protocol, Mr Paisley did not face any prosecution or disciplinary proceedings. He later defended his comments, and his right to say them, in a Radio 4 documentary prior to resigning from government in 2008 following allegations of improper links with property developers. ${ }^{34}$ It appears that the sentiments garnered during the Reverend Dr Ian Paisley's "Save Ulster from Sodomy" crusade remain endemic within the DUP camp. Homosexuality has not only been denigrated, but LGBT communities cited as causes of harm to the immediate and wider society. Such a position was demonstrated in 2005 by DUP MLA Maurice Mills who blamed Gay Pride parades for Hurricane Katrina, which devastated New Orleans and killed over 1300 people. Claiming that it was a message from God, he stated:

The media failed to report that the hurricane occurred just two days prior to the annual homosexual event called the Southern Decadence Festival, which the previous year had attracted an estimated 125,000 people. Surely, this is a warning to nations where such wickedness is increasingly promoted and practised. This abominable and filthy practice and sodomy has resulted in the great continent of Africa being riddled with AIDS, all at great cost to the nations and innocent children. ${ }^{35}$

Mr Mills is councillor for Ballymena which has a large Protestant population and a strong DUP majority. He was not reprimanded for his comments which could be seen as particularly insensitive given the devastation Hurricane Katrina inflicted on thousands of people's lives. Other politicians who have also waded in with publicly homophobic remarks include former Sports Minister Edwin Poots, an evangelical Protestant who criticised the Ulster Titans Rugby Football Club in 2007. The club specifically welcomes gay rugby players but does not exclude heterosexual players. Despite this, Mr Poots accused the team of being bigoted against heterosexuals. Mr Poots had previously voiced homophobic sentiments in a row over the use of a civil venue in Lisburn for civil partnership ceremonies. Mr Poots denounced the notion of civil partnerships, stating that they are not weddings whilst describing the civil partnership law as "wrong and immoral and sticks in the throat". At the same meeting, Cllr Ronnie Crawford of the Ulster Unionist Party (UUP) attacked homosexuality in general, quoting both the current Pope and his predecessor in stating that gay marriage was an "ideology of evil" and that homosexuality was "intrinsically

32 "Paisley censured for homophobic comments", RTE News, 3 February 2005, available at www.rte.ie/news/2005/0203/paisleyi.html.

33 A Erwin, "Paisley Junior under attack for gay 'insult"', Independent (Irish edition), 31 May 2007, available at www.independent.ie/national-news/paisley-junior-under-attack-for-gay-insult-686918.html.

34 "Paisley Jnr resigns as minister", BBC News, 18 February 2008, available at http://news.bbc.co.uk/ 2/hi/uk_news/northern_ireland/7250877.stm.

35 A Chrisafis, "Katrina 'sent by God to punish New Orleans gays", Guardian, 19 November 2005, available at www.guardian.co.uk/uk/2005/nov/19/northernireland.hurricanes2005. 
disordered". 36 Cllr Crawford further stated that he "resented the gay lobby" trying to change everything, though strangely ended his comments by stating that he was tolerant of homosexual acts conducted in private. No action was taken against either of these public servants as a result of the evidently moral position they occupied and the language used in their defamation. This was also the case for DUP minister, Bert Johnston, in a comment opposing the now enacted equality laws:

I don't think God made a mistake when he made us male and female and these people who call themselves gays and the like are essentially perverts. I believe their problems exist only in their minds. It is not a biological or medical condition they suffer from. It is related - and I refer to Romans Chapter I - to the fact that the people who are most often this way inclined are mostly Godless people with reprobate minds. ${ }^{37}$

Again, this comment was heavily influenced by biblical interpretation and utilised biblical terminology, meaning that prosecution was eluded. Not only is the existence of LGBT people and groups abhorred by many of these objectors, but the limited financial support they receive has also come under attack. Many of the LGBT groups in Northern Ireland rely upon piecemeal funding from various bodies and charitable organisations to continue working in and with the wider community, conducting research and providing valuable information. Since the reinstatement of the Northern Ireland Assembly in 2007, they have obtained some of their funding from the government, although the allocation of this funding has come under criticism. Whilst still in post as Northern Ireland Secretary, Peter Hain earmarked $£, 180,000$ to be given to LGBT groups over a period of two years. However, DUP MLA Jim Wells invoked negative imagery in his claims that UK taxpayers were unlikely to be supportive of this move:

I am appalled that this level of money was committed to homosexual support groups behind our backs before devolution. There is very little public support for these projects ... The majority of taxpayers wants nothing to do with funding these groups. I would much prefer that any young person were not encouraged to seek advice from Government funded homosexuality groups. People in their early teens often go through a period of confusion but the vast majority come through these difficult periods, marry and have children. ${ }^{38}$

Mr Wells appears to have based his opinions on conjecture as he gave no evidence to support his claims. Conversely, LGBT support groups in Northern Ireland have produced research which indicates the considerably high levels of self-harm and suicide attempts prevalent amongst such "confused" young people who are constantly presented with discourses of sin and immorality in relation to their sexuality. ${ }^{39} \mathrm{~A}$ third of their respondents cited mental health problems occurring as a result of hiding their sexual identity or by continual exposure to negative ideologies about homosexuality. As this research demonstrated, it is not the sexuality which harms, but the hostile attitudes towards it displayed with relative impunity on a frequent basis.

36 Observations from a meeting held on Tuesday 26 July 2005 at Lisburn City Council. A more detailed transcript can be found at www.sluggerotoole.com/archives/2005/07/jeff_dudgeon_wi.php.

37 “Transsexuals and gays are perverts, says DUP councillor", Impartial Reporter, 19 February 2004, available at www.impartialreporter.com.

38 "MLA 'appalled' at gay support group funding", News Letter, 30 November 2007, available at www.newsletter.co.uk/news/MLA-39appalled39-at-gay-support.3541045.jp.

$39 \mathrm{H}$ McNamee, Out on your Own: An examination of the mental bealth of young same-sex attracted men (Belfast: Rainbow Project 2006). 
None of the articulators of the above comments faced disciplinary or criminal proceedings as a result of their remarks. A review of the laws available, but as yet unused, indicates that by comparison, prosecuting homophobic hatred in Northern Ireland ought to be easier than in England and Wales. However, the fact that no one has been prosecuted leads the discussion of homophobia into wider socio-political territory.

\section{Legislating against homophobia: a redundant move in Northern Ireland?}

Much debate surrounded the incitement to homophobic hatred legislation which was recently enacted in England and Wales. Section 74 and Schedule 16 of the Criminal Justice and Immigration Act 2008 amended the Public Order Act 1986, creating new offences of stirring up hatred on the grounds of sexual orientation. This covers conduct - namely words or behaviour - or material which is threatening in nature and which is intended to stir up hatred against a group of people who are defined by their sexual orientation. The requirement that the accused had the required intention to incite hatred is an issue which some LGBT support groups argue may prove impossible to enforce. The new laws differ from existing incitement to racial or religious hatred in that the words "abusive" and "insulting" have been removed, leaving just "threatening words and behaviour" to be considered in relation to inciting homophobic hostility. However, as the Bill was going through Parliament in 2008, Conservative peer Lord Waddington added a late amendment which cited that discussions or criticisms of homosexual conduct or practices, as well as encouraging people to refrain from or modify such conduct, is not enough to be considered threatening or intent to stir up hatred. As a result, voting ensued on "Clause 61", which was designed to overturn this amendment, but was defeated in the House of Lords in 2009, keeping the religious exemptions in place. ${ }^{40}$ Therefore, a person voicing temperate opposition to same-sex relationships or expressing an opinion on same-sex adoption within the remit of their religious beliefs would not risk prosecution under these incitement laws. ${ }^{41}$ Welcoming the legislation, Ben Summerskill, chief executive of LGBT pressure group Stonewall, said:

The newly-extended criminal offence of incitement to hatred will go some way towards addressing the hatred and violence directed towards lesbians, gay men and bisexuals in Britain at a time when homophobic attacks are on the increase. It sends a strong signal that such behaviour is unacceptable in a civilised society. Just like race, a person's sexual orientation is an intrinsic characteristic for which no citizen should ever feel under threat of verbal or physical violence. ${ }^{42}$

Whilst he is right that this legislation will only impact Great Britain, existing laws protecting public order have already been invoked prior to this specific legislation regarding hostility motivated by sexual orientation. In England, Conservative councillor Peter Willows was found guilty of breaching the Public Order Act 1986 for equating gay people with paedophiles. ${ }^{43}$ In Bournemouth, evangelist Harry Hammond was charged under s. 5 of the Public Order Act 1986 for brandishing a large double-sided sign which read "Stop Immorality", "Stop Homosexuality" and "Stop Lesbianism" on each side provoking an

40 As part of their election campaign, several senior Labour politicians had pledged to overturn the free speech clause if re-elected.

41 Those prosecuted under the "homophobic hatred" law face a maximum punishment of seven years in prison or a fine.

42 J Geen, "Law against homophobic hatred comes into effect", Pink News, 23 March 2010, available at www.pinknews.co.uk/2010/03/23/law-against-homophobic-hatred-comes-into-effect/.

43 "Gay remark councillor convicted", BBC News, 12 December 2006, available at http://news.bbc.co.uk/1/hi/england/southern_counties/6173969.stm. 
angry reaction from some passers-by. ${ }^{44}$ In Scotland, New York preacher Shawn Holes was charged with uttering homophobic and sectarian remarks and fined $£, 1000$ for stating that "Homosexuals are deserving of the wrath of God, and so are all other sinners, and they are going to a place called hell." 45 Homophobia has been challenged in several cases in Europe too. In France, politician Christian Vanneste was the first person to be convicted under French anti-homophobia laws for his comments on the "endangerment" factor of homosexuals. ${ }^{46}$ In Sweden, the legislation has been enforced on numerous occasions, including against a preacher who was considered to be denigrating homosexuality to an unacceptable level in sermons. ${ }^{47}$ However, in Northern Ireland, legislation criminalising homophobic hatred, in place since 2004, remains unused in any prosecutions.

Section 3 of the Criminal Justice (No 2) (Northern Ireland) Order 2004 amended the Public Order (Northern Ireland) Order 1987 to include incitement to hatred on the basis of sexual orientation. Section 9(1)(b) of the 2004 Order states that intent is not necessary if "having regard to all the circumstances hatred is likely to be stirred up or fear is likely to be aroused thereby". ${ }^{48}$ Numerous complaints to the PSNI following Iris Robinson's statements, coupled with outraged newspaper comments, letters pages and online discussion forums outlining people's anger towards her statements resulted in no action being taken. Why, then, might this be the case? Highlighting the same issues which Stonewall was citing to enact the recent law - primarily homophobic lyrics from particular music artists - Liberal Democrat MP David Heath questioned the impact of Northern Ireland's wider socio-political environment on the ability to see the homophobe, rather than the homosexual, at fault:

The slight concern that I have is that the legislation which is already in place in Northern Ireland hasn't yet been used and there is an argument that is repeatedly raised by Stonewall and others about extreme homophobic lyrics. Why has that not been addressed in Northern Ireland? It may be something to do with the particular political situation in Northern Ireland. My worry is once it's on the statute it just stays on the statute book rather than being used in the circumstances where it should properly be used. ${ }^{49}$

Mr Heath's allusion to the "particular political situation in Northern Ireland" somewhat glosses over a deeper problematic issue. The politically sensitive nature of Northern Ireland's history (and present, considering the current debates around the devolving of criminal justice to the Northern Ireland Assembly) may be the central issue in this failure adequately to address homophobic hostility. A key issue may well be the geographical and social climate in which such discussions are occurring, but whether or not this should be a concessionary issue is open for debate. The intersectionality of religion and politics in Northern Ireland is so entrenched that routinely it dominates legal and political decision making. The fact that various changes made to sexual orientation equality legislation and the enhancing of LGBT rights purposefully occurred outside of Northern Ireland's political

44 "Gay group supports campaign to clear homophobic preacher", Pink. News, 25 April 2006, available at www.pinknews.co.uk/news/articles/2005-1267.html/.

45 M Hennessy, "Street preacher fined for 'homosexuals going to hell' remark", Irish Times, 31 March 2010, available at www.irishtimes.com/.

46 P Belien, "Conservative MP fined for homophobia", Brussels Journal, 27 January 2007, available at www.brusselsjournal.com/node/724.

47 Supreme Court of Sweden, ruling 29 November 2005 in case No B 1050-05.

48 Public Order (Northern Ireland) Order 1987 (NI 7), Article 9(1)(b), as amended by the Criminal Justice (No 2) (Northern Ireland) Order 2004, s. 3.

49 T Grew, "Interview: David Heath on incitement to homophobic hatred", Pink News, 3 January 2008, available at www.pinknews.co.uk/news/articles/2005-6446.html. 
remit illustrates this. So too does the ongoing campaign for women's right to choose following the failure to extend the 1967 Abortion Act to Northern Ireland. ${ }^{50}$

As well as not engaging with this legislation due to perceived political sensitivity, there is also the issue that so many comments have been made which could be seen as stirring up fear that it could be problematic to start investigating them all. Commenting on this issue during debates on the English and Welsh legislation in 2007, Mr Don Horrocks, head of public affairs at the Evangelical Alliance, illustrated a potential problem of setting a precedent in this area:

My observation about Northern Ireland, why that has been the case and why the precedents are not necessarily compelling, is that there is a different religious and cultural situation over there. Northern Ireland and the mainland are very different. The police over there are very, very sensitive and concerned about protecting freedom of speech, precisely because of community tensions. The feeling that I get from over there, certainly from what I have been told, is that if any of those laws were used, floodgates could open. There has therefore been a keenness not to use those laws. ${ }^{51}$

Perhaps this comment goes to the heart of why the implementation of laws protecting and enhancing equality on the basis of sexual orientation remains tokenistic in Northern Ireland. Abatement of tensions is the sole focus in Northern Ireland politics, a place where economic prosperity is dependent upon such "community tensions" being kept to the peripheries of society. But this is a society with a deeply entrenched history of segregation, difference and a visible, opposed "other"; a position now being filled by LGBT communities, minority ethnic communities and, increasingly, people from the disabled community. If it is a choice between the lesser of two evils, these communities may find themselves up against memories of a 30-year political conflict to contend with before their claims of what incitement to hatred leads to for them.

\section{The impact on homophobia and LGBT relations}

Homophobic discrimination, victimisation and violence are founded upon seeing lesbians and gay men as different and therefore inviting prejudice. In Northern Ireland, research into the nature and prevalence of victimisation has indicated that lesbians and gay men may constitute acceptable targets of prejudice. ${ }^{52}$ There are few openly lesbian or gay media personalities and those who have "come out" and publicly stated their sexual identity have cited the hostility and victimisation their openness has incurred. ${ }^{53}$ So prevalent were the levels of abuse directed at lesbians and gay men that the various Northern Irish LGBT groups in Belfast felt that the onus was on them rather than the police to take action to address this growing problem. Subsequent contact and collaborations with the PSNI, local education authorities and some faith organisations heralded a decreased level of reported homophobic incidents. ${ }^{54}$ Many of these initiatives have been conceived, and their positive outcomes lauded, at the various Gay Pride events and parades since the enactment of "hate

50 E Fegan and R Rebouche, "Northern Ireland's abortion law: the morality of silence and the censure of agency" (2003) 11(3) Feminist Legal Studies 221-54.

51 Written evidence to be reported to the House, Criminal Justice and Immigration Bill, Public Bill Committees, 18 October 2007, available at www.parliament.the-stationery-office.com/pa/cm200607/cmpublic/criminal/ 071018/pm/71018s01.htm.

52 N Jarman and A Tennant, An Acceptable Prejudice? Homophobic violence and harassment in Northern Ireland (Belfast: Institute for Conflict Research 2003).

53 See N McCafferty, Just Call Me Nell (London: Penguin 2004).

54 www.psni.police.uk/index/statistics_branch.htm. 
crime" legislation in Northern Ireland. Members of the Gay Police Association of Northern Ireland also provide a visible presence at the event, citing a commitment to address victimisation and violence towards members of LGBT communities. As research into the violence of homophobic prejudice suggests, this is a necessary measure.

In 2003, the first and largest study into homophobic harassment and violence in Northern Ireland was conducted by the Institute for Conflict Research (ICR). It noted that, with up to 82 per cent of respondents having incurred some form of victimisation: "the percentage of people who have experienced violence and harassment was higher than indicated by comparable studies in Great Britain and Ireland". 55 This finding supported previous research undertaken by Stonewall in 1996 as part of its UK study into homophobic victimisation and violence. ${ }^{56}$ However, the ICR study also showed that the levels of violence used in assault were increasing, stating that: "there [is] now a greater use of violence and a greater propensity to use violence in such attacks". ${ }^{57}$ In almost half of all incidents the perpetrator was a person known to the victim. ${ }^{58}$ The researchers also found that only 42 per cent of those who had experienced some form of prejudice had reported the incident to the police. One reason cited for this reluctance was the perceived homophobia of members of the PSNI, claims that were somewhat supported by a 2006 investigation into homophobia within the police force. ${ }^{59}$

Both of these studies also highlighted participants' fears of violent retributions from paramilitary group members who may disapprove of homosexuality. ${ }^{60}$ This fear was particularly pertinent among respondents living in rural areas in Northern Ireland where paramilitary control was seen to be more ingrained than in urban areas. This issue was raised in the media by representatives of LGBT groups who warned of both the increasing frequency and ferocity of attacks, particularly on gay men. ${ }^{61}$ In some cases these attacks resulted in the death of victims. The murders of Shaun Fitzpatrick, ${ }^{62}$ Warren "Aaron" McCauley and Ian Flanagan involved a significant level of violence, especially to the face and head areas. ${ }^{63}$ Other attacks on gay men in areas outside Belfast have attracted a similar level of media interest as a result of the violence involved. One gay male victim lost several teeth and required numerous stitches to his face after a particularly vicious attack. ${ }^{64}$ Another young man sustained severe physical injuries and almost lost an eye in an attack involving an attempted gouging. ${ }^{65}$ Whilst the homophobic "hate crime" legislation has been invoked in these cases, recognising the prejudicial element and sentencing the perpetrators

55 Jarman and Tennant, An Acceptable Prejudice, n. 52 above, p. 6.

56 G Mason and A Palmer, Queer Bashing: A national survey of hate crimes against lesbians and gay men (London: Stonewall 1996).

57 Jarman and Tennant, An Acceptable Prejudice, n. 52 above, p. 65.

58 Ibid., p. 29.

59 K Radford, J Betts and M Ostermeyer, Policing, Accountability and the Lesbian, Gay and Bisexual Community in Northern Ireland (Belfast: ICR 2006).

60 Jarman and Tennant, An Acceptable Prejudice, n. 52 above; Radford et al., Policing, n. 59 above.

61 "Gay men targeted in attacks", BBC News, 19 May 2004, available at http://news.bbc.co.uk/1/hi/ northern_ireland/3728345.stm.

62 "Pair guilty of homophobic murder", BBC News, 11 March 2010, available at http://news.bbc.co.uk/2/hi/ uk_news/northern_ireland/foyle_and_west/8562900.stm.

63 “"Gay-bashing' killers jailed”, BBC News, 1 July 2004, available at http://news.bbc.co.uk/1/hi/ northern_ireland/3856839.stm.

64 "Gay man bitten in attack", BBC News, 20 July 2004, available at http://news.bbc.co.uk/1/hi/ northern_ireland/3910109.stm.

65 “"Gay attack' victim may lose eye”, BBC News, 31 January 2006, available at http://news.bbc.co.uk/1/hi/ northern_ireland/4664954.stm. 
accordingly, these cases may illustrate the most severe end of a continuum of prejudice which is not being engaged with at the important "lower-level" end.

When prejudicial sentiments become fundamental to the ethos of a society, the criminalisation of that prejudice may be rendered difficult as the bias it is condemning appears "normal". As Barbara Perry points out, perpetrators may be "doing difference", or acting upon a socially sanctioned prejudice in society. ${ }^{66}$ Interventions therefore need to focus on societal attitudes at large, not just on the perpetrator of the crime. ${ }^{67}$ Examining how societies sustain prejudices which may manifest into violent acts, Gail Mason asserts that:

violence will fail to serve a function for the perpetrators if the prejudicial attitudes undergirding such violence are no longer supported by societal norms or by religious, legal and political doctrines

suggesting that the failure to condemn homophobic attitudes "promotes an atmosphere that condones violence against gay men and lesbians". 68

Already in Northern Ireland, situations where homophobia is both condoned and condemned in the same political breath have indicated that for some members of LGBT communities, theory and practice are still two separate areas in relation to combating homophobia and violence. The impact of this knowledge may be as debilitating as the fear of homophobic violence itself.

\section{Conclusion}

The recent conference held in Belfast by Christian group Core Issues, whose leader Reverend Mario Bergner routinely states that he can convert homosexuals back to heterosexuality, attracted criticism for upholding misguided notions that homosexuality is a condition which can be reversed or changed. In a move which marked a turn of events, members of the Stop Conversion Therapy Taskforce (SCOTT) picketed the church where the conference was being held. However, their targets were not the therapists inside, but the lesbians and gay men in attendance who felt that their sexuality, and not the wider homophobic society, was the problem. ${ }^{69}$ The notion that homosexuality is both curable and mutable is not limited to evangelical laypersons; more problematically, as demonstrated, it is a position taken by elected political elites, including those responsible for the mental health provisions available to lesbians and gay men in Northern Ireland.

This article has demonstrated the lengths people who are morally opposed to homosexuality can go to in expressing their objection with impunity in Northern Ireland. The oppositional arguments against the law being implemented in England and Wales are predicated on the infringement of freedoms of speech for religious preachers and people opposed to homosexuality on the basis of biblical interpretations. However, as has been evidenced in this discussion, it is unlikely that such opposition will face prosecution, especially if there is a need to show "intent" to threaten or incite hatred.

The objectives of Gay Pride parades are not to convert people, to tell them that they are going to hell or that their lifestyles are wrong, harmful and shameful. It would be incredulous to suggest that a group of LGBT people would start picketing a Christian place of worship with banners to this effect about Christianity, but would be no more than a re-

66 Perry, In the Name of Hate, n. 2 above.

67 See J Mouzos and S Thompson, "Gay-hate related homicides: an overview of major findings in NSW" in Trends and Issues in Crime and Criminal Justice (Canberra: Australian Institute of Criminology, June 2000).

68 G Mason, Violence Against Lesbians and Gay Men (Sydney: Duncan Chappell 1993).

69 J Geen, "Anti-gay group to protest outside Christian convention", Pink News, 17 February 2010, available at www.pinknews.co.uk/2010/02/17/anti-gay-cure-group-to-protest-outside-christian-convention/. 
appropriation of the words and images used against themselves. As a result of the intensified debate about morality and sexuality in Northern Ireland, it appears that the Gay Pride parade has perhaps never been so vital for visibility, validity and vitality. In Northern Ireland, it will be interesting to see, whenever it happens, the inaugural prosecution under this offence, in order to clarify just what has to be said to be deemed unacceptable, or perhaps more importantly, who has to say it. 